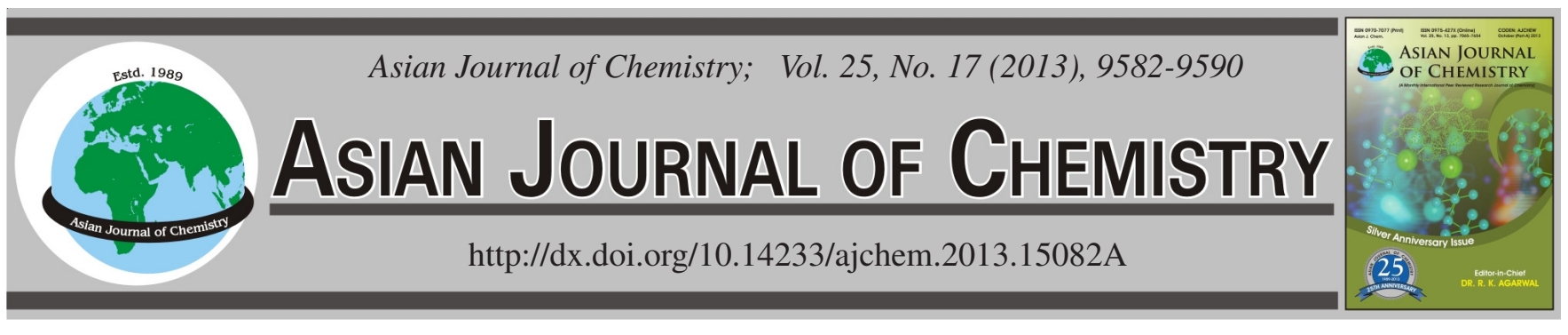

\title{
A Comparative Investigation on Adsorption Performances of Activated Carbon Prepared from Coconut Husk Fiber and Commercial Activated Carbon for Acid Red 27 Dye
}

\author{
Hatem A. Al-Aoh ${ }^{*}$, M. Jamil MaAh, Rosiyah Yahya and M. Radzi Bin Abas
}

Department of Chemistry, Faculty of Science, University of Malaya, 50603 Kuala Lumpur, Malaysia

*Corresponding author: Tel: +60 176243656; E-mail: issa_hatem2@yahoo.com

\begin{abstract}
The adsorption of acid red 27 dye on activated carbon fiber and granular activated carbon were studied in a batch system. The effects of initial concentration, agitation time, solution $\mathrm{pH}$ and temperature were examined. Adsorption isotherms were described using both the Langmuir and Freundlich models at three different temperatures. It was found that, the Langmuir model fits well with the experimental data at each temperature. The pseudo-first-order, pseudo-second-order and intra-particle diffusion models were used to examine the kinetics data. The results obtained showed that the empirical kinetics data of activated carbon fiber at 60 and $100 \mathrm{mg} / \mathrm{L}$ were well described only by the pseudo-second-order model. The intraparticle diffusion was involved at $200 \mathrm{mg} / \mathrm{L}$ for activated carbon fiber and at each tested concentration for granular activated carbon. It was observed that activated carbon fiber has a higher adsorption capacity and adsorption rate than that of granular activated carbon. Adsorption thermodynamic parameters were estimated and the values of $\Delta \mathrm{H}^{\circ}, \Delta \mathrm{S}^{\circ}$ and $\Delta \mathrm{G}^{\circ}$ obtained indicate that the adsorption of acid red 27 on activated carbon fiber and granular activated carbon were exothermic and spontaneous processes.
\end{abstract}

Key Words: Adsorption, Isotherm, Kinetic, Thermodynamic, Coconut husk, Activated carbon, Acid red 27 dye.

\section{INTRODUCTION}

Azo dyes represent the largest and the most important class of the commercial dyes which are generally used in textile and other industries ${ }^{1}$. Acid red 27 dye (AR 27) is the most common category among all of these dyes ${ }^{2}$. It is usually used as colourant in textile for wool and silk, colour photography, paper industries and in food $^{2-4}$. It was discovered that $12 \%$ of the dye is released during the dyeing processes into wastewater ${ }^{5}$. It was also found by studies conducted in Russia that acid red 27 is a carcinogen ${ }^{6}$. The interaction of acid red 27 dye with human hemoglobin in solution was investigated by Wang et al. ${ }^{6}$. They concluded that the binding of acid red 27 with these proteins has toxicological importance. The disposal of the coloured wastewaters poses a major problem for the industry as well as a threat to environment ${ }^{7}$. Therefore, various methods, e.g., ozonation ${ }^{8}$, photocatalytic degradation ${ }^{1,2,9-12}$, oxidation ${ }^{13}$ and others were applied to remove acid red 27 from wastewaters before their discharge to the environment. Although the adsorption technique was used for the removal of acid dyes such as, acid red $73^{14}$, acid red $18^{15,16}$, acid red $14^{17,18}$, acid red $88^{19}$, acid red $97^{20}, \mathrm{ARB}^{21}$ and $\mathrm{ARG}^{22}$. There seems to be only two attempts in the literature that have been carried out by Phan et al. ${ }^{23}$ and Metivier-Pignon et al. ${ }^{24}$ on the adsorption of acid red 27 dye. Phan and his co-worker studied adsorption of acid red 27 onto activated carbon prepared from low cost materials, jute and coconut husk fibers. They found that the maximum adsorption capacities of 62.18 and 49.60 $\mathrm{mg} / \mathrm{g}$ for activated carbon prepared from jute and coconut fibers, respectively. Metivier-Pignon et al. ${ }^{24}$ found higher adsorption capacity for the adsorption of acid red 27 by activated carbon fiber produced from cloths, which are more expensive than the raw materials used for the production of the commercial activated carbon. Therefore, additional work is required to improve the potential of the inexpensive activated carbon prepared from coconut husk fiber towards acid red 27 dye. Thus, the main aim of this work was to investigate adsorption of acid red 27 dye on activated carbon fiber (ACF) prepared from coconut husk under optimal conditions. The second objective was to compare the adsorption performance of activated carbon fiber and commercial granular activated carbon (GAC). The effect of adsorption parameters, adsorption isotherms, kinetic and thermodynamics were investigated in a batch system.

\section{EXPERIMENTAL}

Preparation of activated carbon fiber: The fibers of coconut husk were used for the preparation of activated carbon fibers under optimal conditions using a horizontal tube furnace. 
The optimized experimental conditions were determined prior to the use of $800^{\circ} \mathrm{C}$ as activation temperature, $50 \% \mathrm{w} / \mathrm{v} \mathrm{ZnCl}_{2}$ concentration, $200 \mathrm{~cm}^{3} / \mathrm{min}$ nitrogen flow rate, $2 \mathrm{~h}$ activation time and $300{ }^{\circ} \mathrm{C}$ carbonization temperature. The produced sample was washed once with $1.5 \mathrm{M}$ solution $\mathrm{HCl}$ and several times with deionized water until the $\mathrm{pH}$ of the washing effluent reached 6-7. Finally, the sample was dried at $110^{\circ} \mathrm{C}$ over night in an oven and stored in a dessicator for other uses. The activated carbon fiber produced in this work and the commercial activated carbon (in the granular form) are described as activated carbon fiber and commercial granular activated carbon, respectively.

Characterization of the adsorbents: The specific surface areas of the activated carbon fiber and commercial granular activated carbon were determined by $\mathrm{N}_{2}$ adsorption (at 77.40 $\mathrm{K}$ ), using a surface analyzer (Sorptomatic Thermo Finnigan 1990 , USA). The $t$-method was used to measure the pore structure of these adsorbents. The $\mathrm{pH}$ at the point of zero charge (pHZPC) was determined by a batch equilibrium method. The Fourier Transform Infrared spectroscopy (FT-IR) (Perkin Elmer-2000 FT-IR) measurements were performed to quantify the surface functional groups of these two activated carbons. The surface morphology of the activated carbon fiber and commercial granular activated carbon were examined by scanning electron microscopy (LEO 1455 VP, England).

Preparation of dye solutions: The dye of acid red 27 (AR 27) with chemical and physical properties represented in Table-1 was supplied by Sigma-Aldrich, USA, APEO. The stock solution (10000 mg/L) of acid red 27 was prepared in deionized water. The desired concentrations of the adsorption solutions were obtained by dilution.

\section{TABLE-1}

STRUCTURE AND CHARACTERISTICS OF ACID RED 27 DYE

\section{Adsorption experiments}

Impact of the initial concentration of the adsorbate: To investigate the effect of the initial concentration, adsorption of acid red 27 on activated carbon fiber and commercial granular activated carbon was carried out at various concentrations of the dye solutions $(20,40,60,80,100,200,300,400,500$, $600,700,800,900$ and $1000 \mathrm{mg} / \mathrm{L}$ ) using a fixed amount of adsorbent $(0.03 \mathrm{~g})$ at initial $\mathrm{pH}$, agitation speed $150 \mathrm{rpm}$ and $30 \pm 1{ }^{\circ} \mathrm{C}$ for 4 days to achieve equilibrium. The samples were filtered and the final concentrations of acid red 27 in the filtrate were measured by the UV-visible spectrophotometer (Shimadzu, Japan) at the maximum wave length $420 \mathrm{~nm}$. The equilibrium adsorption amounts were computed from eqn. 1.

$$
\mathrm{q}_{\mathrm{e}}=\frac{\left(\mathrm{C}_{\mathrm{o}}-\mathrm{C}_{\mathrm{e}}\right) \mathrm{V}}{\mathrm{W}}
$$

where $\mathrm{C}_{\mathrm{o}}$ and $\mathrm{C}_{\mathrm{e}}(\mathrm{mg} / \mathrm{L})$ are the initial and final concentrations of acid red 27, respectively, $\mathrm{W}(\mathrm{g})$ is the mass of adsorbent used, $\mathrm{q}_{\mathrm{e}}(\mathrm{mg} / \mathrm{g})$ is the adsorption amount at equilibrium and $\mathrm{V}$ (L) is the volume of the solution.

Isotherm studies: Adsorption of 200, 300, 400, 500 and $600 \mathrm{mg} / \mathrm{L}$ of acid red 27 solution onto fixed amounts $(0.03 \mathrm{~g})$ of activated carbon fiber and granular activated carbon were carried out at 30,45 and $60{ }^{\circ} \mathrm{C}$ in a batch system. These experiments were performed by adding $25 \mathrm{~mL}$ of each solution to $30 \mathrm{~mL}$ amber bottles each of which contained the required amount of activated carbon fiber or granular activated carbon. The amber bottles were sealed and placed in an incubator shaker. The bottles were shaken at the initial $\mathrm{pH}$ and at an agitation speed $150 \mathrm{rpm}$ for 4 days to reach equilibrium. The mixtures were filtered and the final concentrations of acid red 27 in the filtrate were measured by UV-visible spectrophotometer (Shimadzu, Japan) at the acid red 27 dye maximum wave length (420nm). Eqn. 1 was used for calculation of the amounts of this dye adsorbed at equilibrium. The results obtained were used for determination of the adsorption capacities and thermodynamic parameters. The effect of temperature was also investigated using these results.

Kinetic studies: To investigate the effect of the contact time and adsorption kinetics, adsorption of 60, 100 and 200 $\mathrm{mg} / \mathrm{L}$ of acid red 27 onto the prepared activated carbon fiber and the commercial granular activated carbon were performed at the original $\mathrm{pH}$, at an agitation speed of $150 \mathrm{rpm}$ at $30 \pm$ $1{ }^{\circ} \mathrm{C}$ for various time periods. The other experimental processes were carried out as mentioned earlier with the isotherm studies. The adsorption amount at any time $\mathrm{t}(\mathrm{min})$ was computed by the following equation:

$$
\mathrm{q}_{\mathrm{t}}=\frac{\left(\mathrm{C}_{0}-\mathrm{C}_{\mathrm{t}}\right) \mathrm{V}}{\mathrm{W}}
$$

where, $\mathrm{q}_{\mathrm{t}}(\mathrm{mg} / \mathrm{L})$ is the amount of acid red 27 adsorbed at time $\mathrm{t}(\mathrm{mg} / \mathrm{g}) . \mathrm{C}_{\mathrm{o}}$ and $\mathrm{C}_{\mathrm{t}}(\mathrm{mg} / \mathrm{L})$ are the liquid phase concentration at initial and any time $\mathrm{t}$, respectively. $\mathrm{V}$ is the volume of the solution (L) and $\mathrm{W}(\mathrm{g})$ is the mass of adsorbent.

Effect of solution pH: The solutions of acid red 27 dye with initial concentration of $400 \mathrm{mg} / \mathrm{L}$ and various initial $\mathrm{pH}$ values (1-11) were prepared. The $\mathrm{pH}$ of each solution was adjusted to the required value by adding $\mathrm{HCl}$ or $\mathrm{NaOH}$ solutions before mixing the adsorbent using a $\mathrm{pH}$ meter (Model: Ross FE 20, USA). $25 \mathrm{~mL}$ of each solution was added to the $30 \mathrm{~mL}$ amber bottles containing $0.03 \mathrm{~g}$ of the prepared activated carbon fiber. The bottles were sealed and put in a rotational shaker and shaken at room temperature $\left(30 \pm 1^{\circ} \mathrm{C}\right)$ and at an agitation speed of $150 \mathrm{rpm}$ for 4 days. The solid adsorbents were separated from the mixtures by filtration using filter papers. The final concentration of the acid red 27 and the equilibrium adsorption amount were determined according to the isotherm studies.

For comparison, all the procedures mentioned above were repeated with the commercial granular activated carbon.

\section{RESULTS AND DISCUSSION}

Characterization of the activated carbons: The results of the surface analyzer and pHZPC of the activated carbon fiber and granular activated carbon are summarized in Table- 2 . It can be observed from this Table that activated carbon fiber has a higher surface area, total pore volume, mesopore volume 


\begin{tabular}{lcc}
\hline \multicolumn{3}{c}{ TABLE-2 } \\
CHARACTERISTICS OF THE ACF AND ACG \\
\hline \multirow{2}{*}{ Type of activated carbon } & $\begin{array}{c}\text { Activated } \\
\text { carbon fiber }\end{array}$ & $\begin{array}{c}\text { Commercial granular } \\
\text { activated carbon }\end{array}$ \\
\hline Specific surface area $\left(\mathrm{m}^{2} / \mathrm{g}\right)$ & 5435 & 1061 \\
Total pore volume $\left(\mathrm{cm}^{3} / \mathrm{g}\right)$ & 4.043 & 0.559 \\
Micropore volume $\left(\mathrm{cm}^{3} / \mathrm{g}\right)$ & 1.479 & 0.328 \\
Mesopore volume $\left(\mathrm{cm}^{3} / \mathrm{g}\right)$ & 2.564 & 0.231 \\
Average pore diameter $(\AA)$ & 29.76 & 21.06 \\
Micropore $(\%)$ & 36.582 & 58.68 \\
Mesopore $(\%)$ & 63.418 & 41.32 \\
$\mathrm{pH}_{\text {ZPC }}$ & 7.6 & 6.7 \\
\hline
\end{tabular}

and percentage mesopore higher than that of granular activated carbon. This indicates that the prepared activated carbon fiber has higher adsorptive properties than that of the commercial granular activated carbon.

Figs. 1 and 2 represent the SEM photograph of activated carbon fiber produced by this study and commercial granular activated carbon. It can be seen from these figures that the majority of pores on the surface of these adsorbents are mesopores which are more effective in dye adsorption. Moreover, these figures demonstrate that the number of pores on the surface of activated carbon fiber higher than that of granular activated carbon. The results observed in this part are in agreement with the results from the surface analyzer.

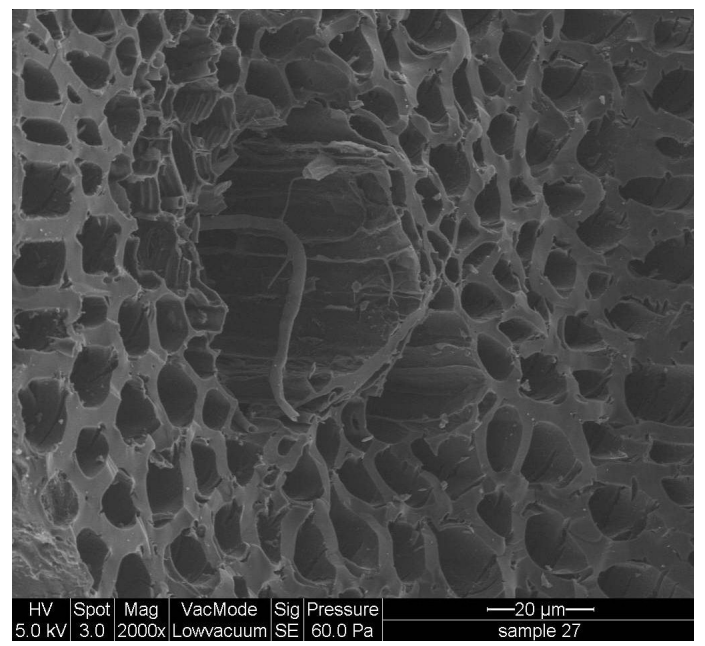

Fig. 1. SEM image of the prepared activated carbon fiber

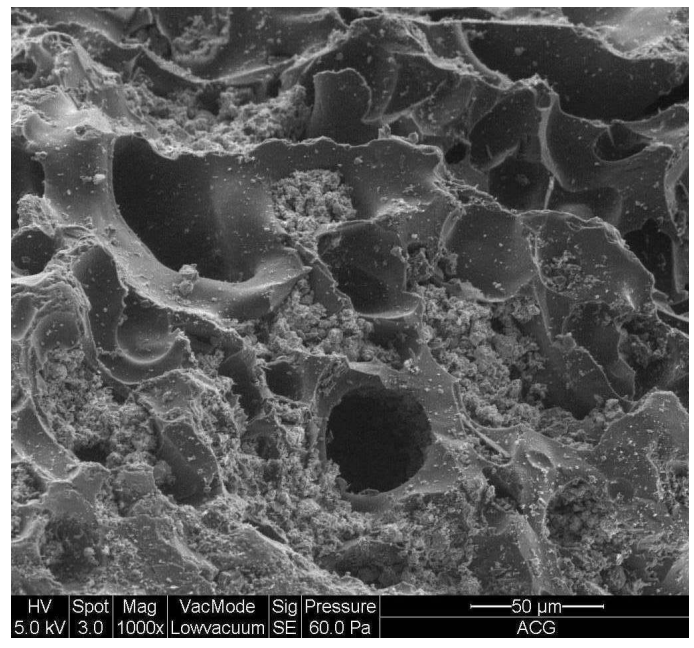

Fig. 2. SEM image of the commercially available granular activated carbon
The FT-IR experiments were performed to evaluate qualitatively the functional groups on the surface of activated carbon fiber and granular activated carbon. The spectra obtained are shown in Fig. 3. It is shown in Fig. 3, that the broad band at $3343.25 \mathrm{~cm}^{-1}$ can be attributed to the presence of a hydroxyl group. The band located at around $2949.53 \mathrm{~cm}^{-1}$ corresponds to $\mathrm{C}-\mathrm{H}$ vibration stretching. The absorption peak recorded in the region of $1057.34 \mathrm{~cm}^{-1}$ is attributed to the symmetrical angular deformation of ethers ${ }^{25}$. There are two absorption peaks that can be observed at around 3434.43 and $1633.36 \mathrm{~cm}^{-1}$ in commercial granular activated carbon. These two peaks are attributed to a hydroxyl group and axial deformation of carbonyl groups $(\mathrm{C}=\mathrm{O})$, respectively.

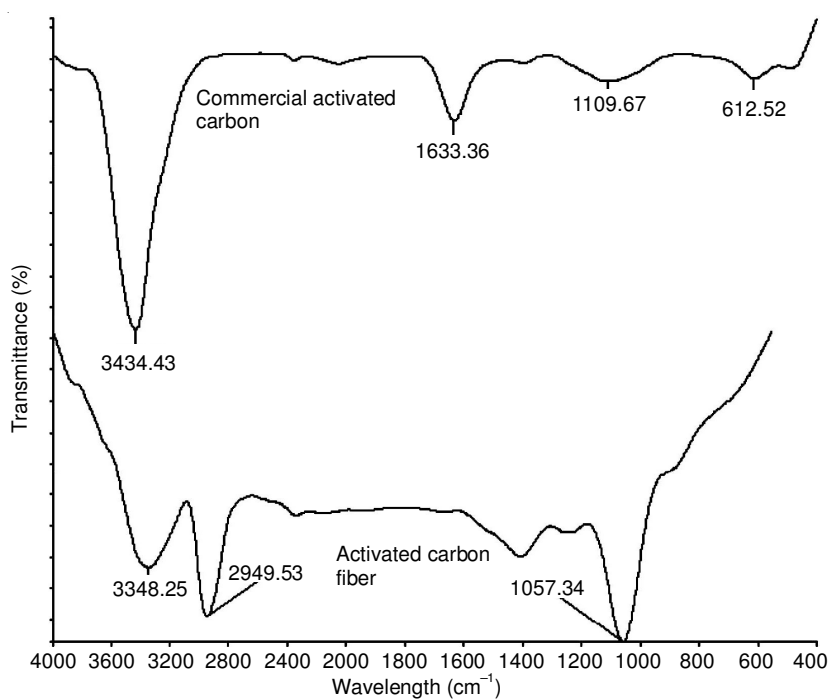

Fig. 3. FT-IR graph of the prepared activated carbon fiber and the commercial granular activated carbon

\section{Adsorption studies}

Effect of initial dye concentration on acid red 27 adsorption: In this work, the effects of the initial dye concentration on the adsorption capacity of acid red 27 were investigated in the range of $20-1000 \mathrm{mg} / \mathrm{L}$ for both activated carbon fiber and granular activated carbon. The results obtained are represented in Fig. 4. As shown in this figure, the amount of acid red 27 dye adsorbed onto activated carbon fiber or granular activated carbon increases as the initial dye concentration is increased. This is due to increasing the driving force which can overcome all the mass transfer resistances of the adsorbate molecules between the liquid and solid phases ${ }^{17,26}$. It can also be observed from Fig. 4 that the adsorption amount of this dye is constant over 600 and $700 \mathrm{mg} / \mathrm{L}$ for granular activated carbon and activated carbon fiber, respectively. This may come from the saturation of the adsorption sites on the surfaces of these carbons as the concentration of acid red 27 is increased over 600 and $700 \mathrm{mg} / \mathrm{L}^{17,26}$. Moreover, it can be seen from Fig. 4 that the adsorption capacity of this dye on the prepared activated carbon fiber is double that of the granular activated carbon. This can be explained by the specific surface area, pore diameter, total pore volume and higher mesopore volume and percentage of activated carbon fiber compared with granular activated carbon (Table-2). Similar results were observed in the literature for the adsorption of azo dye and acid blue 113 


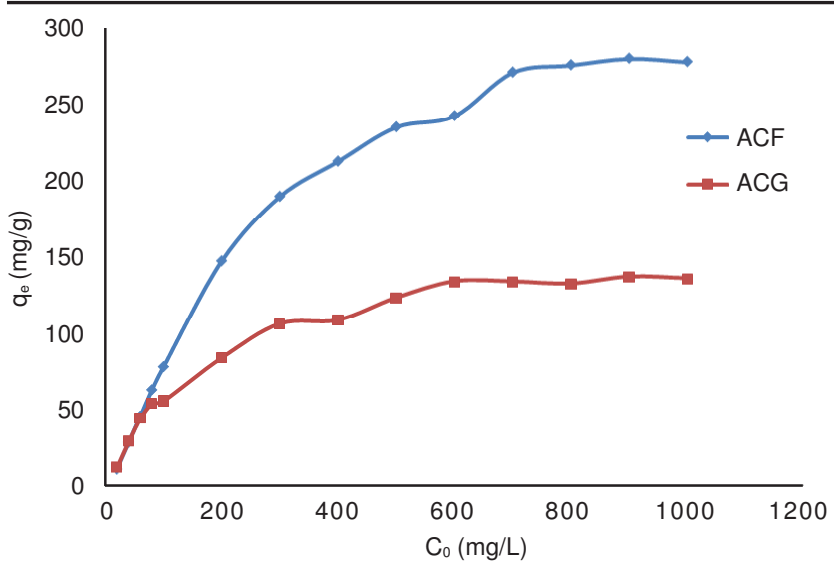

Fig. 4. Effect of initial concentration on the adsorption capacity of acid red 27 dye onto activated carbon fiber and granular activated carbon

onto activated carbon prepared from waste rubber tires and from commercial activated carbon ${ }^{26}$.

Isotherm data analysis: Isotherm data for the adsorption of acid red 27 onto activated carbon fiber and granular activated carbon were applied to the Langmuir and Freundlich models. The results of the linear form of these two models were used to determine the fit of the models. The linearized forms of the Langmuir and Freundlich models are represented in eqns. 3 and 4 , respectively.

$$
\begin{aligned}
& \frac{\mathrm{C}_{\mathrm{e}}}{\mathrm{q}_{\mathrm{e}}}=\frac{1}{\mathrm{q}_{\max } \mathrm{K}_{\mathrm{L}}}+\frac{\mathrm{C}_{\mathrm{e}}}{\mathrm{q}_{\max }} \\
& \ln \mathrm{q}_{\mathrm{e}}=\ln \mathrm{K}_{\mathrm{F}}+\frac{1}{\mathrm{n}} \ln \mathrm{C}_{\mathrm{e}}
\end{aligned}
$$

where, $\mathrm{q}_{\mathrm{e}}$ is the amount of an adsorbate adsorbed at equilibrium $(\mathrm{mg} / \mathrm{g}), \mathrm{q}_{\max }$ the maximum adsorption capacity corresponding to a complete monolayer coverage on the surface $(\mathrm{mg} / \mathrm{g}), \mathrm{C}_{\mathrm{e}}$ is the concentration of the adsorbate at equilibrium $(\mathrm{mg} / \mathrm{L})$. $\mathrm{K}_{\mathrm{L}}$ is the Langmuir constant related to the energy or net enthalpy of adsorption. $\mathrm{K}_{\mathrm{F}}$ is the Freundlich constant related to the adsorption capacity. $1 / \mathrm{n}$ is another constant in the Freundlich model related to the favorability of adsorption. Since, if the value of $1 / \mathrm{n}$ is between 0 and 1 , this indicates that the adsorption is favorable ${ }^{27}$.

The essential characteristics of the Langmuir isotherm can be expressed by a dimensionless factor called the equilibrium parameter $\mathrm{R}_{\mathrm{L}}$ defined by eqn. $5^{28}$.

$$
\mathrm{R}_{\mathrm{L}}=\frac{1}{1+\mathrm{K}_{\mathrm{L}} \mathrm{C}_{0}}
$$

where, $\mathrm{K}_{\mathrm{L}}$ is the Langmuir constant and is the highest adsorbate concentration. The value of $\mathrm{R}_{\mathrm{L}}$ indicates the type of isotherm, either unfavorable $\left(R_{L}>1\right)$, linear $\left(R_{L}=1\right)$, favorable $\left(0<R_{L}\right.$ $<1)$ or irreversible $\left(R_{L}=0\right)$.

The obtained values of the isotherm parameters, correlation coefficient $\left(\mathrm{R}^{2}\right)$ and $\mathrm{R}_{\mathrm{L}}$ values are listed in Table-3.

Figs. 5 and 6 demonstrate that the plots of Langmuir model for activated carbon fiber and granular activated carbon at three different temperatures are linear over the whole concentration range which were used. It can also be seen from Table- 3 that the correlation coefficients of the Langmuir model varied from 0.986-0.997 for activated carbon fiber and from 0.912-0.984 for granular activated carbon.

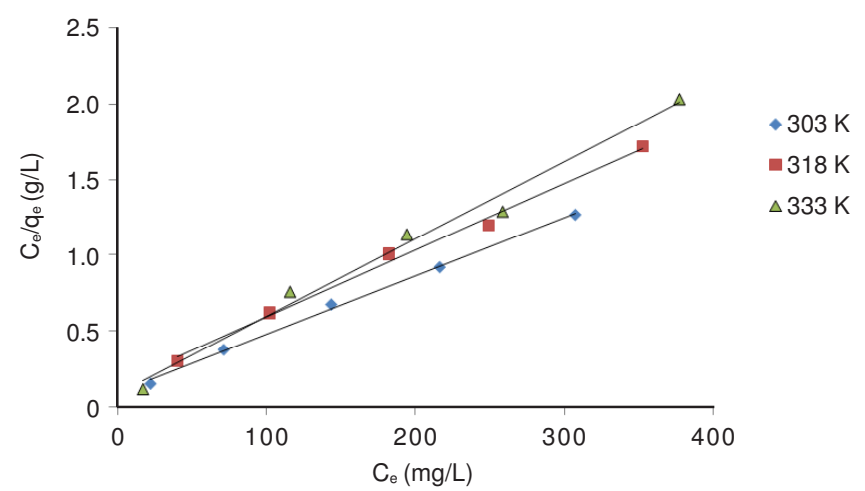

Fig. 5. Langmuir isotherm model at three different temperatures for adsorption of acid red 27 dye on activated carbon fiber

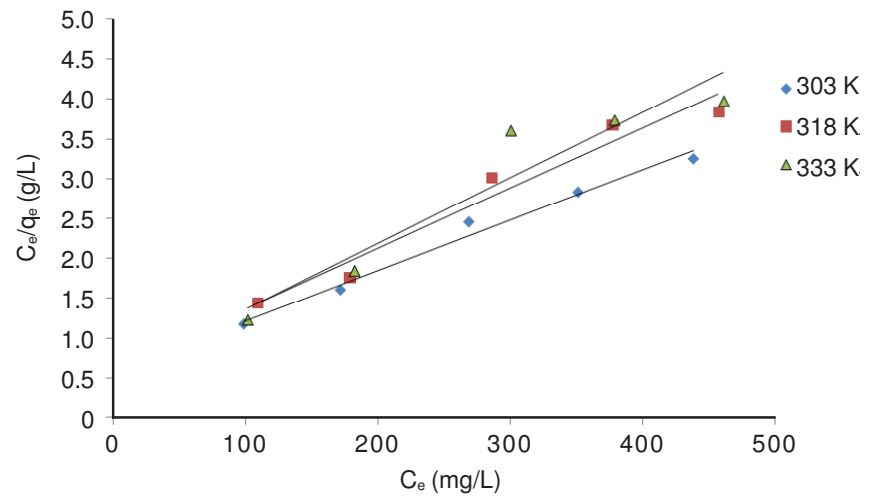

Fig. 6. Langmuir isotherm model at three different temperatures for adsorption of acid red 27 dye on commercial granular activated carbon

In contrast, the plots of the Freundlich model (Figs. 7 and 8 ) at three different temperatures for both adsorbents are not linear. Moreover, the correlation coefficients of Freundlich model ranged from 0.581 to 0.993 for activated carbon fiber and from 0.476 to 0.949 for granular activated carbon.

These results suggest that the Langmuir model satisfactorily fits the adsorption of acid red 27 on the prepared activated

TABLE-3

LANGMUIR, FREUNDLICH PARAMETERS AND SEPARATION FACTORS (RL) FOR THE ADSORPTION OF ACID RED 27 ONTO ACTIVATED CARBON FIBER (ACF) AND GRANULAR ACTIVATED CARBON (ACG) AT THREE DIFFERENT TEMPERATURES

\begin{tabular}{cccccc|cccc}
\hline \multirow{2}{*}{ Adsorbent } & $\begin{array}{c}\text { Temperature } \\
\left({ }^{\circ} \mathrm{C}\right)\end{array}$ & \multicolumn{3}{c|}{ Langmuir isotherm } & \multicolumn{4}{c}{ Freundlich isotherm } \\
\cline { 3 - 11 } & $\mathrm{q}_{\max }(\mathrm{mg} / \mathrm{g})$ & $\mathrm{K}_{\mathrm{L}}(\mathrm{L} / \mathrm{mg})$ & $\mathrm{R}_{\mathrm{L}}$ & $\mathrm{R}^{2}$ & $\mathrm{~K}_{\mathrm{F}}(\mathrm{mg} / \mathrm{g})(\mathrm{L} / \mathrm{mg})^{1 / \mathrm{n}}$ & $1 / \mathrm{n}$ & $\mathrm{n}$ & $\mathrm{R}^{2}$ \\
\hline \multirow{3}{*}{$\mathrm{ACF}$} & 30 & 333.33 & 0.034 & 0.047 & 0.997 & 82.27 & 0.192 & 5.21 & 0.993 \\
& 45 & 250 & 0.023 & 0.058 & 0.994 & 60.95 & 0.213 & 4.69 & 0.966 \\
& 60 & 200 & 0.064 & 0.026 & 0.986 & 118.75 & 0.075 & 13.33 & 0.581 \\
\hline \multirow{3}{*}{ ACG } & 30 & 166.67 & 0.010 & 0.143 & 0.984 & 22.49 & 0.291 & 3.44 & 0.949 \\
& 45 & 142.86 & 0.011 & 0.132 & 0.959 & 24.58 & 0.249 & 4.02 & 0.764 \\
& 60 & 125 & 0.015 & 0.100 & 0.912 & 38.86 & 0.162 & 6.17 & 0.476 \\
\hline
\end{tabular}




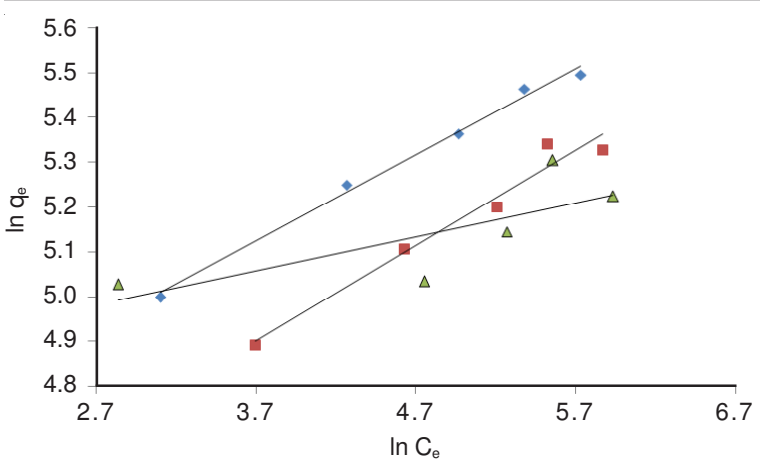

Fig. 7. Freundlich isotherm model at three different temperatures for adsorption of acid red 27 on activated carbon fiber

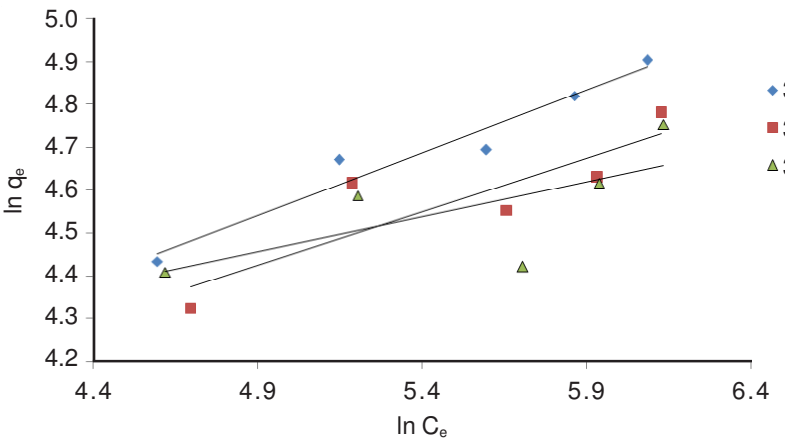

Fig. 8. Freundlich isotherm model at three different temperatures for adsorption of acid red 27 on granular activated carbon

carbon fiber and the commercial granular activated carbon. Similar results were observed in the adsorption of acid blue 113 on the activated carbon prepared from waste rubber tires and commercially activated carbon ${ }^{26}$.

The values of $R_{L}$ (Table-3) in the case of activated carbon fiber are smaller than that of commercial granular activated carbon at each temperature, indicating that the adsorption of this dye on activated carbon fiber is more favorable than that of granular activated carbon. Furthermore, it can be observed from Table-3 that the prepared activated carbon fiber at each temperature adsorption capacity is higher than the adsorption capacity of the commercial granular activated carbon. This is due to the superior surface area and porosity of the prepared activated carbon fiber.

Effect of temperature: Adsorption isotherms of acid red 27 dye on activated carbon fiber and granular activated carbon were investigated at 30,45 and $60^{\circ} \mathrm{C}$. The results of this investigation are summarized in Table- 3 . It can be seen from this Table that the adsorption capacities of activated carbon fiber and granular activated carbon decrease with increasing the adsorption temperature. This indicates that the adsorption of acid red 27 onto activated carbon fiber and granular activated carbon is an exothermic process ${ }^{29,30}$. It was reported by Ozcan and $\mathrm{Ozcan}^{31}$ that the amount of adsorption of the acid red 57 on a surfactant-modified sepiolite decreased with increasing temperature.

Determination of thermodynamic parameters: The enthalpy $\left(\Delta \mathrm{H}^{\circ}\right)$ and entropy $\left(\Delta \mathrm{S}^{\circ}\right)$ change values were computed from slopes and intercepts of the lines plotted (Figs. 9 and 10) according to eqn. 6 while the values of the free energy change $\left(\Delta \mathrm{G}^{\mathrm{o}}\right)$ were calculated at three different temperature from eqn. 7.

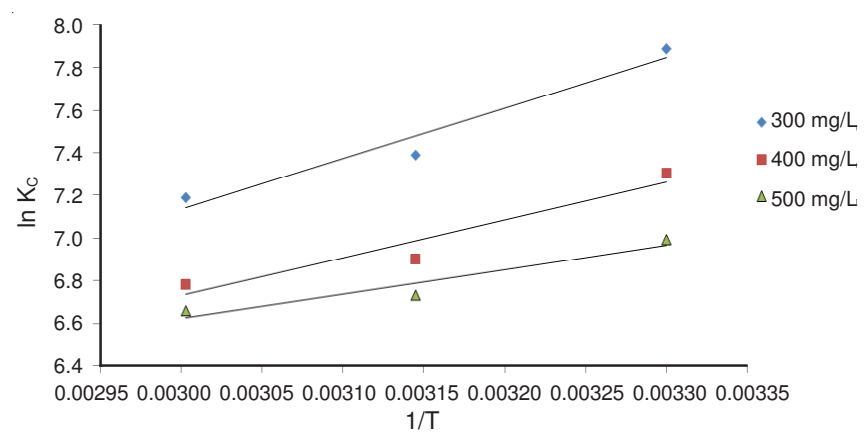

Fig. 9. Variation of $\ln \mathrm{K}_{\mathrm{C}}$ with $1 / \mathrm{T}$ for the adsorption of acid red 27 on activated carbon fiber at three different initial concentrations

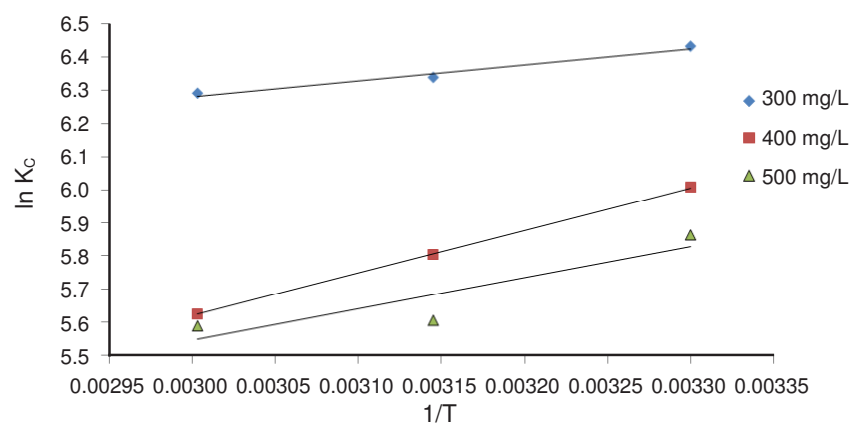

Fig. 10. Variation of $\ln \mathrm{K}_{\mathrm{C}}$ with $1 / \mathrm{T}$ for the adsorption of acid red 27 on granular activated carbon at three different initial concentrations

$$
\begin{aligned}
\ln \mathrm{K}_{\mathrm{C}} & =-\frac{\Delta \mathrm{H}^{\mathrm{o}}}{\mathrm{RT}}+\frac{\Delta \mathrm{S}^{\mathrm{o}}}{\mathrm{R}} \\
\mathrm{K}_{\mathrm{C}} & =\frac{\mathrm{q}_{\mathrm{e}}}{\mathrm{C}_{\mathrm{e}}} \times \mathrm{P} \\
\Delta \mathrm{G}^{\mathrm{o}} & =\Delta \mathrm{H}^{\mathrm{o}}-\mathrm{T} \Delta \mathrm{S}^{\mathrm{o}}
\end{aligned}
$$

where, $\mathrm{R}$ is the universal gas constant $(8.314 \mathrm{~J} / \mathrm{K} \mathrm{mol})), \mathrm{T}$ is the adsorption temperature $(\mathrm{K})$ and $\mathrm{P}$ is the density of the solution $(\mathrm{P}=1000 \mathrm{~g} / \mathrm{L})$. The calculated values of these parameters are summarized in Table- 4 . The negative values of $\Delta \mathrm{H}^{\circ}$ indicate that the adsorption of acid red 27 onto activated carbon fiber and granular activated carbon is an exothermic in nature ${ }^{30}$. The heat of adsorption $\left(\Delta \mathrm{H}^{\circ}\right)$ for activated carbon fiber at each concentration is higher than that of granular activated carbon, indicating that the adsorption of acid red 27 onto activated carbon fiber is more temperature-sensitive ${ }^{30}$. The positive values of entropy change $\left(\Delta S^{\circ}\right)$ indicates that the raised randomness during the adsorption of acid red 27 onto activated carbon fiber and granular activated carbon. is due to liberation of water molecules from the hydrated species of the adsorbent ${ }^{32}$. The negative values of the free energy change $\left(\Delta \mathrm{G}^{\mathrm{o}}\right)$ suggest that the adsorption of this dye on these two adsorbents is a spontaneous process. This means no energy from outside the adsorption system is required ${ }^{32}$. The results obtained in this work are in agreement with the results observed in the adsorption of acid oranges 7 and 10 onto ethylenediamine-modified magnetic chitosan nanoparticles ${ }^{32}$.

Effect of pH: The interactions between the functional groups of the adsorbent surface and the adsorbate are affected by the solution $\mathrm{pH}^{15}$. Therefore, this parameter is very important in the adsorption process. In this work, the effects of $\mathrm{pH}$ on the adsorption of acid red 27 onto activated carbon fiber and 


\begin{tabular}{|c|c|c|c|c|c|c|c|}
\hline \multirow{3}{*}{ Adsorbent } & \multicolumn{6}{|c|}{$\begin{array}{l}\text { TABLE-4 } \\
\text { THERMODYNAMIC PARAMETERS FOR THE ADSORPTION OF ACID RED } 27 \text { ONTO } \\
\text { ACTIVATED CARBON FIBER (ACF) AND GRANULAR ACTIVATED CARBON (ACG) }\end{array}$} & \\
\hline & \multirow{2}{*}{$\begin{array}{c}\text { Concentration } \\
(\mathrm{mg} / \mathrm{L})\end{array}$} & \multirow{2}{*}{$\Delta \mathrm{H}^{\circ}(\mathrm{kJ} / \mathrm{mol})$} & \multirow{2}{*}{$\Delta \mathrm{S}^{\circ}(\mathrm{KJ} / \mathrm{mol})$} & \multicolumn{4}{|c|}{$\Delta \mathrm{G}^{\mathrm{o}}(\mathrm{KJ} / \mathrm{mol})$} \\
\hline & & & & $303 \mathrm{~K}$ & $318 \mathrm{~K}$ & $333 \mathrm{~K}$ & $\mathrm{R}^{2}$ \\
\hline \multirow{3}{*}{ ACF } & 300 & -19.73 & 0.0001 & -19.7603 & -19.7618 & -19.7633 & 0.953 \\
\hline & 400 & -14.72 & 0.0118 & -18.2954 & -18.4724 & -18.6494 & 0.925 \\
\hline & 500 & -9.52 & 0.0265 & -17.5495 & -17.947 & -18.3445 & 0.919 \\
\hline \multirow{3}{*}{ ACG } & 300 & -3.95 & 0.0404 & -16.1912 & -16.7972 & -17.4032 & 0.974 \\
\hline & 400 & -10.73 & 0.0145 & -15.1235 & -15.341 & -15.5585 & 0.999 \\
\hline & 500 & -7.83 & 0.0226 & -14.6778 & -15.0168 & -15.3558 & 0.815 \\
\hline
\end{tabular}

granular activated carbon have been demonstrated in Fig. 11. As shown in this figure, the maximum adsorption capacity was at $\mathrm{pH}=1$ for both activated carbon fiber and granular activated carbon. It can also be seen from Fig. 11 that the adsorption amount decreases with increasing $\mathrm{pH}$. Where, $\mathrm{pHZPC}$ is the $\mathrm{pH}$ value at which the surface charge of the adsorbent equals to zero ${ }^{15}$. The pHZPC was investigated in this work and found to be 7.8 and 6.4 for activated carbon fiber and granular activated carbon, respectively. The adsorbent surface in the solution is positively charged at solution $\mathrm{pH}$ $<\mathrm{pHZPC}$ and negatively charged if the solution $\mathrm{pH}$ is higher than $\mathrm{pHZPC}^{33}$. it was reported previously that some acidic dyes such as acid yellow and acid red 18 are negatively charged even in highly acid solution due to the presence of sulfonic groups and $\mathrm{N}=\mathrm{N}$ bonds in their structure ${ }^{34}$. Thus, increasing $\mathrm{pH}$ from 1 until the value equal to $\mathrm{pHZPC}$ reduces the electrostatic attraction between the positive charge of the adsorbent surface and the negative ions of acid red 27 whereas, increasing the solution $\mathrm{pH}$ over $\mathrm{pHZPC}$ increases the electrostatic repulsion between the negative ions of this dye and the negative surface of the adsorbent. In both the cases mentioned above, the adsorption amount would be decreased. Similar trends were reported in the literature for adsorption of food dyes such as acid yellow 6 , acid yellow 23 and acid red 18 on activated carbon prepared from flamboyant pods ${ }^{15}$.

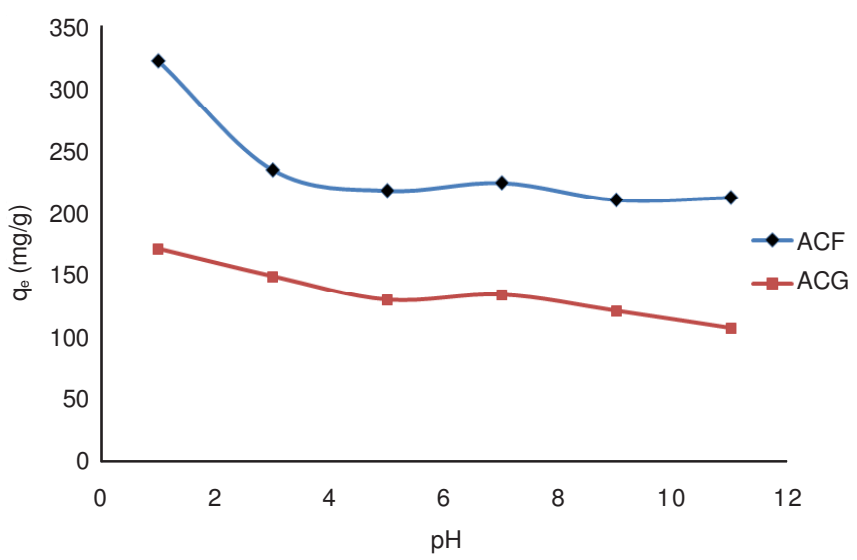

Fig. 11. Effect of $\mathrm{pH}$ on the adsorption of acid red 27 onto activated carbon fiber and granular activated carbon

Effect of contact time: The plots of $\mathrm{q}_{\mathrm{t}}(\mathrm{mg} / \mathrm{g})$ against $\mathrm{t}$ ( $\mathrm{min}$ ) for the adsorption of acid red 27 at different initial concentrations by activated carbon fiber and granular activated carbon are presented in the Figs. 12 and 13, respectively. Fig. 12 demonstrates that the amount of acid red 27 uptake by activated carbon fiber increased with increased agitation time and reached

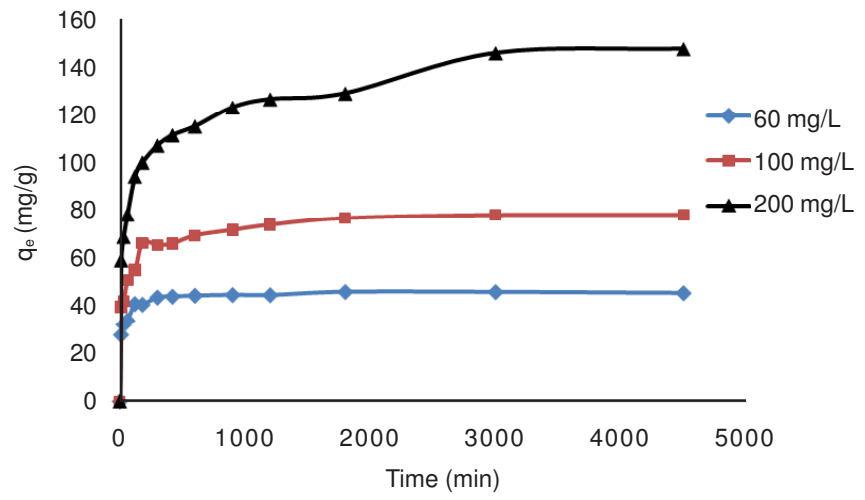

Fig. 12. Effect of the adsorption time on the uptake of acid red 27 by activated carbon fiber at three initial concentrations $(60,100$ and $200 \mathrm{mg} / \mathrm{L})$

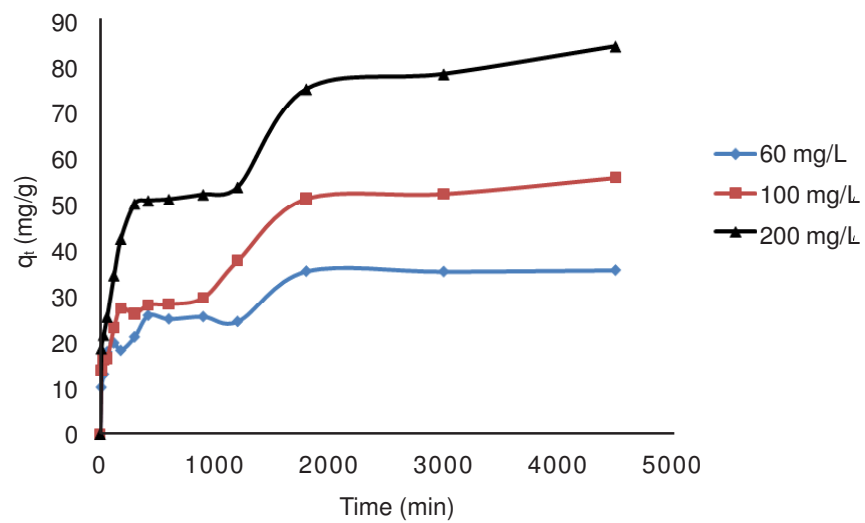

Fig. 13. Effect of the adsorption time on the uptake of acid red 27 by granular activated carbon at three initial concentrations $(60,100$ and 200 $\mathrm{mg} / \mathrm{L}$ )

equilibrium at $180 \mathrm{~min}$ for the solutions of 60 and $100 \mathrm{mg} / \mathrm{L}$. it can also be seen from Fig. 12 that the adsorption of $200 \mathrm{mg} / \mathrm{L}$ acid red 27 solution by the same adsorbent sharply increased when the time is increased from 10 to $180 \mathrm{~min}$, slightly increased in the range of 180 to $1800 \mathrm{~min}$ and the maximum adsorption was achieved at $4500 \mathrm{~min}$. While, the amount of acid red 27 adsorbed onto the commercial granular activated carbon rapidly increased when the adsorption contact time increased from 10 to $420 \mathrm{~min}$, it remained constant until $1200 \mathrm{~min}$ and the maximum adsorption was obtained in $1800 \mathrm{~min}$ (Fig. 13). This indicates that the acid red 27 molecules at first were adsorbed rapidly by the mesopores until this type of pores were saturated. It takes a longer time for these molecules to be adsorbed by the micropores. The results obtained confirm that the adsorption rate of the prepared activated carbon fiber is higher than of granular activated carbon. This is due to the higher average pore diameters of activated carbon fiber (Table-2). 
TABLE-5

PSEUDO-FIRST AND PSEUDO-SECOND ORDER PARAMETERS AND EXPERIMENTAL QE VALUES FOR THE ADSORPTION OF ACID RED 27 DYE BY ACF AND ACG AT DIFFERENT INITIAL CONCENTRATIONS AND $30 \pm 1{ }^{\circ} \mathrm{C}$

\begin{tabular}{|c|c|c|c|c|c|c|c|c|c|}
\hline \multirow{2}{*}{ Adsorbent } & \multirow{2}{*}{$\mathrm{C}_{0}(\mathrm{mg} / \mathrm{L})$} & \multirow{2}{*}{$\mathrm{q}_{\mathrm{e}, \mathrm{exp}}(\mathrm{mg} / \mathrm{g})$} & \multicolumn{3}{|c|}{ Pseudo-first-order kinetic model } & \multicolumn{4}{|c|}{ Pseudo-second-order kinetic model } \\
\hline & & & $\mathrm{q}_{\mathrm{e}, \mathrm{cal}}(\mathrm{mg} / \mathrm{g})$ & $\mathrm{K}_{1}\left(\mathrm{~h}^{-1}\right)$ & $\mathrm{R}^{2}$ & $\mathrm{q}_{\mathrm{e}, \mathrm{cal}}(\mathrm{mg} / \mathrm{g})$ & $\mathrm{K}_{2}(\mathrm{~g} / \mathrm{mg} \min )$ & $\mathrm{R}^{2}$ & Rate \\
\hline \multirow{3}{*}{$\mathrm{ACF}$} & 60 & 45.51 & 11.19 & 0.0023 & 0.882 & 47.62 & 0.00120 & 0.999 & 0.057 \\
\hline & 100 & 78.33 & 28.84 & 0.0023 & 0.770 & 76.92 & 0.00047 & 0,998 & 0.036 \\
\hline & 200 & 148.12 & 70.15 & 0.0000 & 0.872 & 125 & 0.00025 & 0.999 & 0.031 \\
\hline \multirow{3}{*}{ ACG } & 60 & 35.69 & 20.46 & 0.0000 & 0.824 & 27.03 & 0.00071 & 0.984 & 0.019 \\
\hline & 100 & 55.72 & 36.90 & 0.0000 & 0.661 & 30.30 & 0.00094 & 0.997 & 0.028 \\
\hline & 200 & 84.26 & 57.68 & 0.0000 & 0.799 & 58.82 & 0.00026 & 0.995 & 0.015 \\
\hline
\end{tabular}

Kinetic data analysis: The data found from the experiments of the effect of contact time studies were further used to investigate the adsorption kinetics. Three kinetic models, namely, pseudo-first-order, pseudo-second-order ${ }^{35}$ and intraparticle diffusion models were applied to determine the adsorption rate constant and equilibrium adsorption capacity at three different initial concentrations. The linear form of the pseudo-first-order model is:

$$
\log \left(\mathrm{q}_{\mathrm{e}}-\mathrm{q}_{\mathrm{t}}\right)=\log \mathrm{q}_{\mathrm{e}}-\mathrm{K}_{1} \frac{\mathrm{t}}{2.303}
$$

where, $\mathrm{q}_{\mathrm{e}}$ and $\mathrm{q}_{\mathrm{t}}(\mathrm{mg} / \mathrm{g})$ are the adsorption amount at the point of equilibrium and any time $\mathrm{t}(\mathrm{min})$, respectively. $\mathrm{K}_{1}\left(\mathrm{~min}^{-1}\right)$ is the rate constant of the adsorption which can be computed from the slope of the straight-line plot of eqn. 8. The values of $\mathrm{q}_{\mathrm{e}}$ can be obtained from the intercepts of these straight-line plots.

The linear expression of the pseudo-second-order model is:

$$
\frac{\mathrm{t}}{\mathrm{q}_{\mathrm{t}}}=\frac{1}{\mathrm{~K}_{2} \mathrm{q}_{\mathrm{e}}^{2}}+\frac{\mathrm{t}}{\mathrm{q}_{\mathrm{e}}}
$$

where, $\mathrm{K}_{2}(\mathrm{~g} / \mathrm{mg} \mathrm{min})$ is the rate constant of this model which can be determined from the intercept of the straight-line plot of $t / q_{t}$ verses $t$, whereas, $\mathrm{q}_{\mathrm{e}}$ was calculated from the slope of this plot.

The intraparticle diffusion equation is:

$$
\mathrm{q}_{\mathrm{t}}=\mathrm{K}_{\text {dif }} \sqrt{\mathrm{t}}+\mathrm{C}
$$

where, $K_{\text {dif }}(\mathrm{mg} / \mathrm{g} \mathrm{min})^{1 / 2}$ is the rate constant of the intraparticle diffusion which can be calculated from the slope of the straightline plot of $\mathrm{q}_{\mathrm{t}}$ against $\mathrm{t}^{1 / 2}$ and the intercept of this plot is equal to the parameter $\mathrm{C}$ which gives information about the thickness of the boundary-layer ${ }^{36}$. The plots of these kinetic models for the adsorption of acid red 27 by activated carbon fiber and granular activated carbon are represented in the Figs. 14-19. The calculated kinetic parameters in this work are summarized in Tables 5 and 6. According to the correlation coefficient $\left(\mathrm{R}^{2}\right)$ values of the pseudo-first-order kinetic model (Table-5) and the calculated $\mathrm{q}_{\mathrm{e}}$ values, which are too low compared to experimental $\mathrm{q}_{\mathrm{e}}$ values, it can be suggested that the adsorption of acid red 27 by activated carbon fiber and granular activated carbon cannot be described by this kinetic model. The $\mathrm{R}^{2}$ values and the agreement between the experimental $\mathrm{q}_{\mathrm{e}}$ values and the calculated ones (Table-5) for the adsorption at 60 and 100 $\mathrm{mg} / \mathrm{L}$ of this dye suggest that the adsorptions of these two concentrations onto activated carbon fiber follow the pseudosecond-order kinetic model. Although, the correlation coeffi-

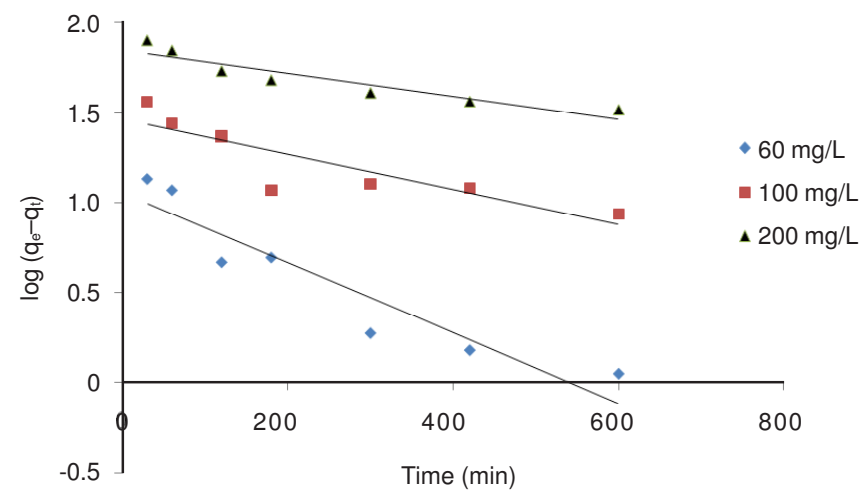

Fig. 14. Pseudo first-order kinetics plots for the adsorption of acid red 27 onto activated carbon fiber at different initial concentrations

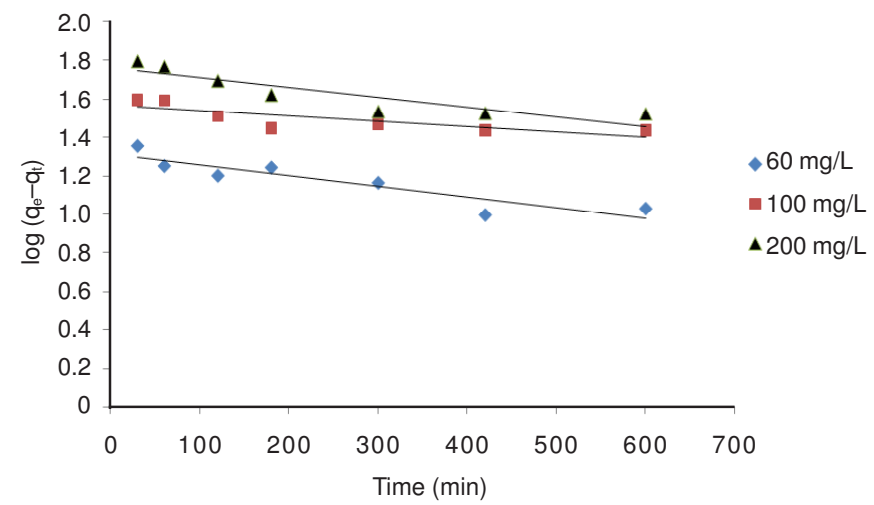

Fig. 15. Pseudo first-order kinetics plots for the adsorption of acid red 27 onto granular activated carbon at different initial concentrations

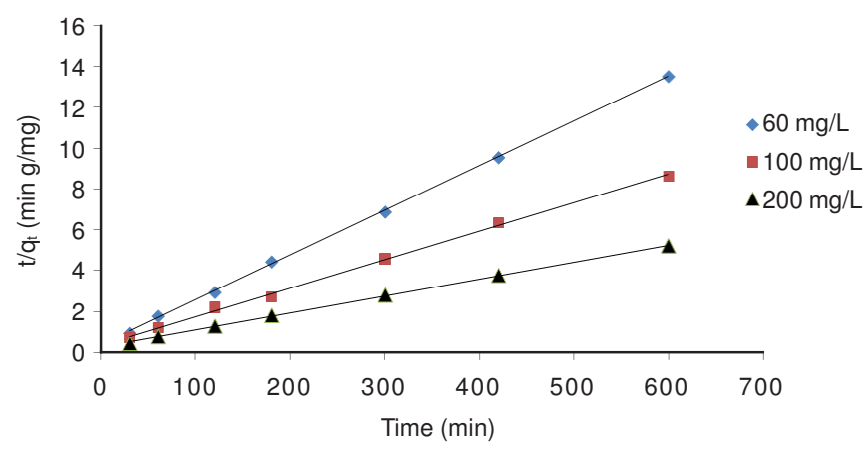

Fig. 16. Pseudo second-order kinetics plots for the adsorption of acid red 27 onto activated carbon fiber at different initial concentrations

cient for the adsorption of $200 \mathrm{mg} / \mathrm{L}$ is 0.999 , the calculated equilibrium adsorption capacity value $(125 \mathrm{mg} / \mathrm{g})$ is not in agreement with that obtained experimentally $(148.12 \mathrm{mg} / \mathrm{g})$. Therefore, these results demonstrate that the pseudo-secondorder kinetic model cannot describe well the adsorption process 


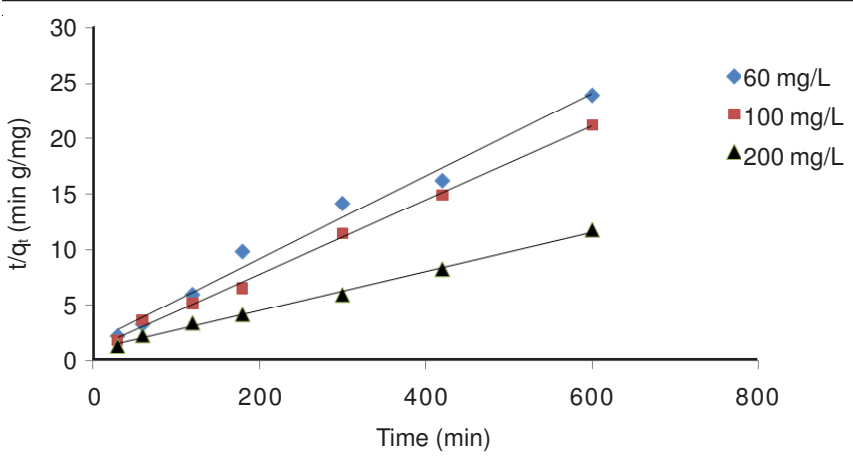

Fig. 17. Pseudo second-order kinetics plots for the adsorption of acid red 27 onto granular activated carbon at different initial concentrations

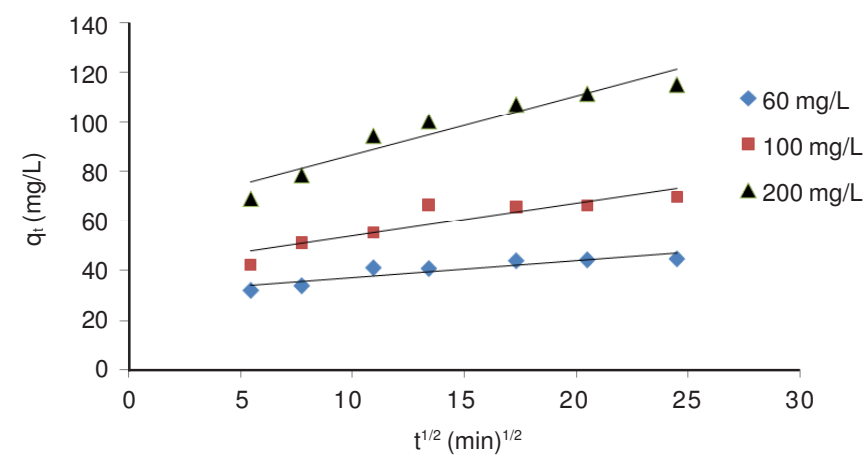

Fig. 18. Intra-particle diffusion for the adsorption of acid red 27 onto activated carbon fiber at different initial concentrations

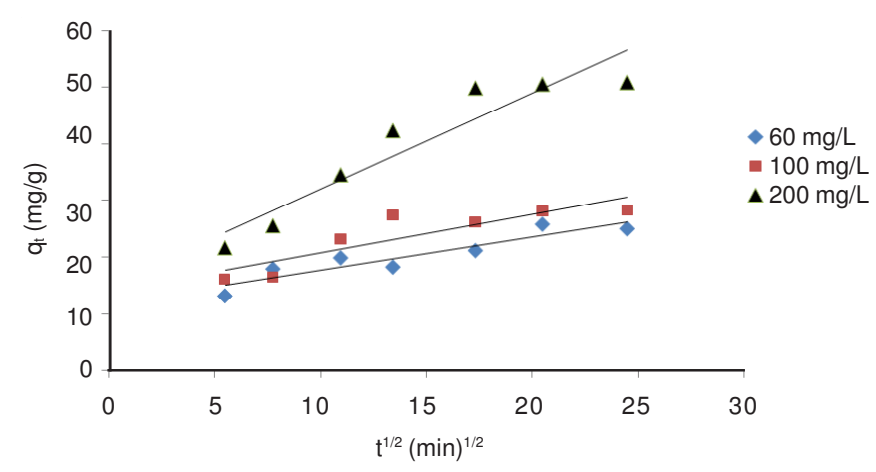

Fig. 19. Intra-particle diffusion for the adsorption of acid red 27 onto granular activated carbon at different initial concentrations

of acid red 27 at higher concentration $(200 \mathrm{mg} / \mathrm{L})$. Moreover, $\mathrm{R}^{2}$ values of the intraparticle diffusion (Table-6) are 0.820 , 0.813 and 0.911 for the adsorption of 60,100 and $200 \mathrm{mg} / \mathrm{L}$ of acid red 27 onto activated carbon fiber, respectively. This confirms that the intraparticle diffusion was only involved in the adsorption process at $200 \mathrm{mg} / \mathrm{L}$. This means that at higher concentrations of acid red 27 , some molecules are adsorbed rapidly by the mesopores available on the surface of activated carbon fiber until this type of pores become saturated and a longer time is required for adsorption of the other molecules by micropores. Despite, the higher values of $\mathrm{R}^{2}$ for the pseudosecond-order in the case of acid red 27 adsorption on granular activated carbon, there is no agreement between the calculated $\mathrm{q}_{\mathrm{e}}$ values and the experimental $\mathrm{q}_{\mathrm{e}}$ values (Table-5). These results assume that the adsorption process of AD 27 by granular activated carbon does not fit well with the pseudo-secondorder kinetic model. The $\mathrm{R}^{2}$ values of the intraparticle diffusion
(Table-6) are higher than that of the pseudo-first-order kinetic model. Figs. 13 and 19 indicate that the intraparticle diffusion mechanism is involved in the adsorption of this dye onto granular activated carbon at each concentration which had been used in this work. This can be explained by the small value of the percentage of available mesopores (Table-2) on the surface of granular activated carbon compared to that of the activated carbon fiber. Therefore, intraparticle diffusion was involved in the adsorption of this dye on activated carbon fiber at 200 $\mathrm{mg} / \mathrm{L}$ and at each concentration in the case of granular activated carbon.

TABLE-6

PARAMETER VALUES OF INTRA-PARTICLE DIFFUSION

MODEL FOR THE ADSORPTION OF ACID RED 27 DYE

BY ACF AND ACG AT DIFFERENT INITIAL CONCENTRATIONS AND $30 \pm 1{ }^{\circ} \mathrm{C}$

\begin{tabular}{lccccc}
\hline \multirow{2}{*}{ Sample } & $\mathrm{C}_{0(\mathrm{mg} / \mathrm{L})}$ & \multirow{2}{*}{$\begin{array}{c}\text { qe.exp } \\
(\mathrm{mg} / \mathrm{g})\end{array}$} & & \multicolumn{3}{c}{ Intra-particle diffusion } \\
\cline { 4 - 6 } & & $\mathrm{K}_{\text {dif }}$ & $\left.\mathrm{mg} / \mathrm{h}^{1 / 2} \mathrm{~g}\right)$ & $\mathrm{C}$ & $\mathrm{R}^{2}$ \\
\hline \multirow{3}{*}{$\mathrm{ACF}$} & 60 & 45.51 & 0.659 & 30.51 & 0.820 \\
& 100 & 78.33 & 1.345 & 40.23 & 0.813 \\
& 200 & 148.12 & 2.404 & 60.41 & 0.911 \\
\hline \multirow{3}{*}{ ACG } & 60 & 35.69 & 0.591 & 11.71 & 0.854 \\
& 100 & 55.72 & 0.685 & 13.90 & 0.778 \\
& 200 & 84.26 & 1.699 & 15.15 & 0.891 \\
\hline
\end{tabular}

It can be observed from Table-5 that the rate of acid red 27 adsorption onto activated carbon fiber is higher than that of the granular activated carbon. This came from the higher average pore diameter of activated carbon fiber compared to that of the granular activated carbon as shown in Table-2.

\section{Conclusion}

Coconut husk fiber was used as a starting material for the preparation of activated carbon fiber. The physical and chemical properties of the prepared activated carbon fiber (ACF) and a commercially available granular activated carbon (ACG) were investigated. The results obtained indicated that the adsorptive properties of activated carbon fiber (for example: $5435 \mathrm{~m}^{2} / \mathrm{g}$ surface area and $2.564 \mathrm{~cm}^{3} / \mathrm{g}$ mesopores volume) are better than that of granular activated carbon $\left(1061 \mathrm{~m}^{2} / \mathrm{g}\right.$ surface area and $0.231 \mathrm{~cm}^{3} / \mathrm{g}$ mesopores volume). Langmuir and Freundlich models were applied to investigate the adsorption isotherms for the adsorption of acid red 27 dye at three different temperatures and it was found that the experimental data could be described well by the Langmuir model.

The maximum adsorption capacity for activated carbon fiber $(333.33 \mathrm{mg} / \mathrm{g})$ is higher than that of granular activated carbon $(166.67 \mathrm{mg} / \mathrm{g})$ at $30^{\circ} \mathrm{C}$. The Adsorption kinetics were analyzed by pseudo-first-order, pseudo-second-order and intraparticle diffusion kinetic models. The kinetic experimental data followed the pseudo-second order model at lower concentration and the intraparticle diffusion was involved at higher concentrations in the case of activated carbon fiber. The intraparticle diffusion mechanism was involved in the adsorption of this dye onto granular activated carbon at each concentration. It was observed that the adsorption rate of acid red 27 on activated carbon fiber was higher than that for granular activated carbon. Thermodynamic parameters such as $\Delta \mathrm{H}^{\circ}$, 
$\Delta \mathrm{S}^{\mathrm{o}}$ and $\Delta \mathrm{G}^{\mathrm{o}}$ were calculated. The values of the parameters confirmed that the adsorption affinity of activated carbon fiber towards acid red 27 is more significant than that of granular activated carbon. In general, the results obtained suggest that the activated carbon fiber used in this work can be applied for wastewater treatment and is superior than the commercial granular activated carbon.

\section{ACKNOWLEDGEMENTS}

This research was supported by the University of Malaya through a Postgraduate Research Grant PV035-2011A.

\section{REFERENCES}

1. N. Daneshvar, M. Rabbani, N. Modirshahla and M.A. Behnajady, $J$. Photochem. Photobiol. A: Chem., 168, 39 (2004).

2. P. Yadav and R.C. Meena, Scholars Res. Library, 2, 66 (2010).

3. M. Karkmaz, E. Puzenat, C. Guillard and J.M. Herrmann, Appl. Catal. B, 51, 183 (2004).

4. R. Zhang, C. Zhang, X. Cheng, L. Wang, Y. Wu and Z. Guan, J. Hazard. Mater, 142, 105 (2007).

5. M. Perez-Urquiza, R. Ferrer and J.L. Beltran, J. Chromatogr. A, 883, 277 (2000)

6. Y.-Q. Wang, H.-M. Zhang and B.-P. Tang, J. Photochem. Photobiol. B, 100, 76 (2010).

7. A.C. Silvaa, J.S. Pic, G.L. Sant'Anna Jr. and M. Dezotti, J. Hazard. Mater., 169, 965 (2009).

8. A.E. Kandjani, M.F. Tabriz, N.A. Arefian, M.R. Vaezi, F. Halek and S.K. Sadrnezhaad, Water Sci. Technol., 6, 1256 (2010).

9. M.A. Behnajady, N. Modirshahla, N. Daneshvar and M. Rabbani, J. Hazard. Mater, 140, 257 (2007).

10. N. Daneshvar, M. Rabbani, N. Modirshahla and M.A. Behnajady, J. Hazard. Mater. B, 118, 155 (2005).

11. N. Daneshvar, M. Rabbani, N. Modirshahla and M.A. Behnajady, Chemosphere, 56, 895 (2004).

12. Puttaswamy, K.N. Vinod and K.N.N. Gowda, Dyes Pigm., 78, 131 (2008).

13. M.G. Colonna, T. Caronna and B. Marcandalli, Dyes Pigm., 41, 211 (1999).

14. F. Fu, Y. Xiong, B. Xie and R. Chen, Chemosphere, 66, 1 (2007).
15. A.M.M. Vargas, A.L. Cazetta, A.C. Martins, J.C.G. Moraes, E.E. Garcia, G.F. Gauze, W.F. Costa and V.C. Almeida, Chem. Eng. J., 181-182, 243 (2012)

16. T. Jesionowski, M. Pokora, W. Tylus, A. Dec and A. Krysztafkiewicz, Dyes Pigm., 57, 29 (2003).

17. Q. Baocheng, Z. Jiti, X. Xuemin, Z. Chunli, Z. Hongxia and Z. Xiaobai, J. Environ. Sci., 20, 704 (2008).

18. J.-F. Gao, J.-H. Wang, C. Yang, S.-Y. Wang and Y.-Z. Peng, Chem. Eng. J., 171, 967 (2011).

19. S.T. Akar and R. Uysal, Chem. Eng. J., 162, 591 (2010).

20. V. Gomez, M.S. Larrechi and M.P. Callao, Chemosphere, 69, 1151 (2007).

21. R. Wu, J. Qu, H. He and Y. Yu, Appl. Catal. B-Environ., 48, 49 (2004).

22. D.S. Tong, C.H. Zhou, Y. Lu, H. Yu, G.F. Zhang and W.H. Yu, Appl. Clay Sci., 50, 427 (2010).

23. N.H. Phan, S. Rio, C. Faur, L.L. Coq, P.L. Cloirec and T.H. Nguyen, J. Carbon, 44, 2569 (2006).

24. H. Metivier-Pignon, C. Faur and P.L. Cloirec, Chemosphere, 66, 887 (2007).

25. S. Karagöz, T. Tay, S. Ucar and M. Erdem, Bioresour. Technol., 99, 6214 (2008).

26. V.K. Gupta, B. Gupta, A. Rastogi, S. Agarwal and A. Nayak, J. Hazard. Mater, 186, 891 (2011).

27. G. Atun, G. Hisarli, W.S. Sheldrick and M. Muhlerler, J. Colloid Interf. Sci., 261, 32 (2003).

28. T.W. Weber and P. Chakkravorti, AIChE J., 220 (1974).

29. Y.S. Ho and G. McKay, J. Environ Sci. Health A, 34, 1179 (1999).

30. A. Ozer, G. Akkaya and M. Turabik, Chem. Eng. J., 112, 181 (2005).

31. A. Ozcan and A.S. Ozcan, J. Hazard. Mater. B, 125, 252 (2005).

32. L. Zhoua, J. Jin, Z. Liu, X. Liang and C. Shang, J. Hazard. Mater., 185, 1045 (2011).

33. D. Prahas, Y. Kartika, N. Indraswati and S. Ismadji, Chem. Eng. J., 140, 32 (2008).

34. N.F. Cardoso, E.C. Lima, I.S. Pinto, C.V. Amavisca, B. Royer, R.B. Pinto, W.S. Alen-car and S.F.P. Pereira, J. Environ. Manage., 92, 1237 (2011).

35. Y.S. Ho, J. Hazard. Mater, 136, 681 (2006).

36. F. Ahmad, W.M.A.W. Daud, M.A. Ahmad and R. Radzi, Chem. Eng. J., 178, 461 (2011). 